\title{
Retaining a New Format: Jazz-Rap, Cultural Memory, and the New Cultural Politics of Difference
}

\section{Jesse Stewart}

In the late 1980s and early 1990s, an influential strain of alternative hip-hop known as "jazz-rap" emerged. ${ }^{1}$ As the term implies, jazz-rap frequently incorporates elements of jazz, either through recorded samples or through live instrumentation. In addition, jazz-rap is often characterized by politically oriented, socially progressive lyrics. This essay examines the jazz-rap trend of the early 1990s, focusing in particular on early recordings by jazz-rap pioneers Stetsasonic, Gang Starr, and Guru, and on the 1994 compilation album Stolen Moments: Red Hot + Cool and the roughly contemporaneous film of the same name, both of which document a historic convergence of hip-hop and jazz musicians in support of AIDS research.

\section{Jazz Things: Early Developments in “Jazz-Rap”}

Dialogue between jazz and hip-hop cultures has a lengthy history that goes back at least as far as jazz pianist Herbie Hancock's 1983 collaboration “Rockit” with hip-hop DJ Grand Mixer D.St. However, it wasn't until 1988 that hip-hop artists began to incorporate elements of jazz into their recordings in a sustained way. One of the first groups to do so was Stetsasonic, widely regarded as one of the first hip-hop bands in that they featured not only MCs and a DJ, but also drums and keyboards in some incarnations. In 1988, Stetsasonic released "Talkin' All That Jazz," which references jazz both musically and lyrically. The piece is structured around a sample of Cecil McBee's bass line from Lonnie Liston Smith's funky soul-jazz classic "Expansions," released on a 1974 album of the same name. The lyrics of "Talkin' All That Jazz" were a response, in part, to a conversation between writer Nelson George and percussionist James Mtume that was broadcast on New York's KISS-FM in 1988. During the interview, Mtume-who had first risen to prominence as a percussionist with Miles Davis in the 1970s, recording on On the Corner and other albums of the period-criticized rap music, focusing in particular on rap's reliance on sampling: "this is the first generation of African-Americans not to be extending the range of the music" he disparaged, claiming that sampling rendered hiphop artless, nothing but "Memorex music" (qtd. in George 89). In response, the lyrics of “'Talkin' All That Jazz" take aim at Mtume, and any would-be critics of hip-hop culture, forcefully declaring the music's status as art. ${ }^{2}$

Of particular interest in the present context are the multiple signifying roles that jazz plays in "Talkin' All That Jazz." On one hand, the piece posits a connection between Stetsasonic's music and jazz in making the case for rap as art, but at the same time, the song asserts rap's originality:

Stop, check it out my man

This is the music of a hip-hop band

Jazz, well you can call it that

But this jazz retains a new format.

As Richard Shusterman notes in his extended analysis of the piece,

The band accepts its identification with jazz, as the most respected black cultural form and tradition to which hip-hop is genealogically attached. But the acceptance is somewhat hesitant. For rap does not want to be seen as a mere variety of jazz, not even of progressive jazz; it rather insists on its originality. Rap's jazz, unlike standard jazz already appropriated by the establishment, "retains a new format," sustains novelty and freshness by maintaining a closer link to changing popular experience and vernacular expression[.] (Pragmatist 220)

Thus, the phrase "retains a new format" encapsulates the complex and conflicted relationships between jazz and hiphop cultures that lie at the heart not only of this piece, but also of jazz-rap generally. Although hip-hop may retain certain musical features and conceptual frameworks associated with jazz and other Afrological forms-notably an emphasis on improvisation, quotation, Signifyin[g] revision, cyclical rhythm, and call and response-hip-hop clearly constitutes a new musical format that extends the range of Afrological creative expression, even as it memorializes its musical past. 
The ambiguity of the relationship between Stetsasonic's music and jazz is reinforced in their video of "Talkin' All That Jazz": directed by old-school hip-hop Renaissance man Fab Five Freddy, it received airplay on Yo! MTV Raps, a program that began airing in 1988, the year the audio track of "Talkin' All That Jazz" was released. With the lyrics "Jazz, well you can call it that," the setting in the video changes from a New York City street scene to the interior of a club where musicians clad in suits, black berets, and sunglasses-all signifiers of modern jazz in this context-play upright bass and drum set. ${ }^{3}$ However, they are not the only performers on stage: Prince Paul, dressed in the same attire as the other musicians, plays turntables with the group, thereby providing a visual reminder that Stetsasonic's jazz "retains a new format." The video further inflects our understanding of the connections between jazz and hip-hop cultures through the inclusion of film fragments taken from Mura Dehn's footage of Savoy Ballroom dancers shot in the 1950s. ${ }^{4}$ Interspersed with scenes of the jazz-club interior and footage of the rappers performing in the street, the acrobatic moves of the lindy hoppers remind the viewer that the improvised physicality of the toprock, downrock, and power moves of hip-hop b-boys and b-girls also have precedents in earlier Afrological forms.

In response to the widespread criticism of digital sampling (of which Mtume's radio diatribe was but one example), ${ }^{5}$ Stetsasonic offers the following defense:

Tell the truth, James Brown was old

'Til Eric and Rak came out with "I Got Soul"

Rap brings back old R\&B

And if we would not, people could've forgot.

The reference here is to Eric B and Rakim's "I Know You Got Soul" from their groundbreaking 1987 record Paid in Full, an album that played a pivotal role in precipitating hip-hop's enduring preoccupation with James Brown samples. ${ }^{6}$ Stetsasonic emphasizes the important role that hip-hop sampling plays in memorializing the musical and cultural past, exposing younger generations of listeners to the rich legacy of Afrological forms. But "Talkin' All That Jazz" goes further in asserting the importance of hip-hop sampling to processes of cultural memorialization, and in its challenge to the cultural establishment surrounding hip-hop culture:

And what we sample of is a majority

But you're a minority in terms of thought

Narrow-minded and poorly taught

About hip-hop aims; all the silly games

To erase my music so no one can use it.

By claiming the music they sample constitutes a majority, they acknowledge the worldwide fecundity and influence of Afrological forms, and situate hip-hop culture within this continuum. In contrast, they declare would-be critics of hiphop, those who would deny its status as art, a "minority in terms of thought," thereby inverting the discursive power dynamics surrounding hip-hop at the time. Stetsasonic also criticizes the efforts of the cultural establishment to erase their music "so no one can use it." This prescient statement suggests that the processes of musical and cultural memorialization evident in "Talkin' All That Jazz," and in hip hop sampling generally, will continue in the future. In much the same way that Stetsasonic's music draws on earlier Afrological forms—on jazz in particular-their music issues a call to future generations of musicians to remix, remember, and retain "a new format."

Stetsasonic was not alone in their explorations of jazz in the late 1980s. In 1989, the hip-hop duo Gang Starr, consisting of rapper/lyricist Guru and DJ Premiere, released their first single: "Words I Manifest." In addition to samples of James Brown's "Bring it Up (Hipster's Avenue)" and Big Daddy Kane's "Word to the Mother(Land)," "Words I Manifest" features a prominent sample of Charlie Parker's classic 1946 recording of "A Night in Tunisia." The piece begins with the lyrics

I profess and I don't jest cause the words I manifest

They will take you, sedate you, and I will stress 
Upon you the need for, you all to feed your

Minds and souls, so you can lead your

Self to peace.

I got a real objective here.

Guru's "real objective": to encourage the feeding of minds and souls, stood in marked contrast to the dominant themes of gangsta rap that, in 1989, were beginning to influence hip-hop cultures on both coasts of the United States. Just as the name of the group-Gang Starr-signifies on the terms "gangster" and "gangsta," the duo's music at the time provided an alternative to the all-too-often violent and misogynist lyrics of gangsta rap, encouraging instead the development of "knowledge, wisdom, understanding," to quote another line from "Words I Manifest." References to jazz played an important role in articulating the group's socially conscious message.

The sample of "A Night in Tunisia" in "Manifest" is just one example among many in Gang Starr's early discography. DJ Premiere's frequent use of jazz bass lines, horn shots, and piano riffs (in addition to sampling staples such as James Brown and The Meters) created a jazz-oriented alternative to both the stripped-down, bass-heavy production style associated with emergent forms of West Coast gangsta rap and the densely layered aesthetic of Public Enemy's production team, the Bomb Squad. ${ }^{7}$ Premiere remembers: "During the time I started making beats, a lot of people were using James Brown, which I was too. But I wanted something different that would work with Guru's vocal style, so I started using jazz samples" (qtd. in Nicholson 140). Guru's trademark vocal style_characterized by a relaxed, almost monotone, quality-articulates a sense of coolness musically that is closer in many respects to the style and flow of "cool jazz" performers than it is to the hard-edged style of many gangsta rappers.

The importance of jazz to Gang Starr's message in the late 1980s is most clearly evident in the tracks "Jazz Music" and "Jazz Thing." Structured around a relaxed hip-hop groove and a recurrent sample of jazz pianist Ramsey Lewis's version of "Les Fleur," "Jazz Music" provides a cogent history of jazz in three and a half minutes. Beginning with references to African musical and cultural heritage, the piece goes on to discuss the transplantation of Africans to America under slavery; the New Orleans jazz of Jelly Roll Morton, King Oliver, and Louis Armstrong; the migration of jazz to Chicago and New York; the swing bands of Benny Goodman, Duke Ellington, and Count Basie; and several additional figures in jazz including Coleman Hawkins, Lester Young, Billie Holiday, Dizzy Gillespie, Charlie Parker, and Miles Davis. The piece suggests that through the work of these musicians, jazz traveled back across the oceans, influencing modes of music making the world over. "Jazz Music" concludes with the lyrics "This is the music, that we give tribute to / They gave it to us, that's why we give it to you / The jazz music," thereby providing a particularly clear example of hip-hop's potential to serve as a form of cultural memory that remembers not only jazz, but also the social and cultural histories surrounding it. ${ }^{8}$

Released in 1989, "Jazz Music" attracted the attention of acclaimed film director Spike Lee, who asked Gang Starr to create another jazz-themed piece for his 1990 film Mo' Better Blues, which chronicles the struggles of an African American jazz trumpeter. ${ }^{9}$ The result was "Jazz Thing," a piece that plays during the closing credits of the movie. In addition to the film version of the piece, which features Gang Starr and the Branford Marsalis Quartet plus Terence Blanchard (who supplied the rest of the music in the film), Gang Starr created an alternate mix for the "Jazz Thing" video that minimizes Marsalis's contributions. Both versions begin with a collage of short musical samples drawn from classic jazz recordings by Charlie Parker, Thelonious Monk, and others, as well as samples that name several prominent jazz musicians including Parker and Billie Holiday. These samples are interspersed with record scratching by DJ Premiere, and a sample of Gang Starr's own "Jazz Music," symbolically situating the duo's music as part of the jazz lineage outlined by this brief introduction. Similarly, the video for "Jazz Thing" features black-and-white archival footage of many jazz musicians including Parker, Holiday, Monk, Duke Ellington, Charles Mingus, John Coltrane, Ornette Coleman, and others, as well as footage of African American lindy hop/jitterbug dancers. These scenes are interspersed with footage of Guru and DJ Premiere in performance, and with scenes from the film Mo' Better Blues. Like the archival footage of jazz musicians, the scenes with Guru and DJ Premiere are in black and white. The duo also wear fedora-style hats and sunglasses that, like the berets and sunglasses in the video for "Talkin' All That Jazz," function as signifiers of jazz culture and help to further articulate connections between jazz and Gang Starr's music.

The lyrics of "Jazz Thing," written in part by Lolis Eric Elie (a high-school friend of Branford Marsalis) with additions and modifications by Gang Starr, delve even more deeply into jazz history than the piece's predecessor. Like "Jazz Music," "Jazz Thing" begins with a discussion of Africa-“or should I say the mother?" asks Guru, who goes on to outline a history of jazz that touches on not only key figures (Scott Joplin, Bessie Smith, King Oliver, Louis Armstrong, Charlie Parker, Dizzy Gillespie, Thelonious Monk, Charles Mingus, Max Roach, John Coltrane, Ornette Coleman, 
Betty Carter, and Sonny Rollins), but also particular pieces (“St. Louis Blues," "Basin St. Blues," "Ornithology," "Anthropology," "Epistrophy," "Oleo," etc).

As Guru moves along the historical jazz timeline, his rapped lyrics become more abstract, reflecting, in a way, the growing emphasis on musical abstraction that characterizes the development of modern jazz, ${ }^{10}$ for example in the verse about John Coltrane:

\title{
John Coltrane, a man supreme
}

He was the cream

He was the wise one

The impression of Afro Blue

And of the promise that was not kept

He was a giant step.

Guru doesn't simply name Coltrane recordings; rather, he describes John Coltrane's music and his effects on the world of jazz by signifyin(g) on numerous Coltrane song and album titles including A Love Supreme, "Wise One," Afro-Blue Impressions, "The Promise," and Giant Steps. The reference to "the promise that was not kept" also hints at the oppressive social conditions that surrounded Coltrane's music, as well as those surrounding jazz, hip-hop, and African American experience more generally. I see this as a reference to the failure of North American society to deliver on its promises of social and economic equality for African Americans. ${ }^{11}$

This idea is developed in the lyrics that follow in which Guru discusses the music of Ornette Coleman: "He was another soul man / The original invisible, playing great music / I wonder why the bankers couldn't use it." His description of Coleman as the "original invisible" can be read in several ways: "Invisible" is the title of the first track on Ornette Coleman's first recording as a leader The Music of Ornette Coleman: Something Else!!!; I am also tempted to read this description in light of Ralph Ellison's Invisible Man, a novel that tells the story of an unnamed African American man who feels as though he is invisible to the dominant social order because of his race. The implication is that the musical innovations of Ornette Coleman were similarly rendered invisible by/to dominant society, not only because of Ornette's race, but also because "the bankers couldn't use it," unlike many previous forms of jazz that had been successfully co-opted by largely white-owned commercial interests surrounding the music.

Guru is more explicit on the history of racial discrimination and the appropriation of Afrological forms in the following verse:

\author{
Now listen see \\ The real mystery is how music history \\ Created Paul Whiteman or any other white man
}

That pretended he originated

And contended that he innovated

A jazz thing.

With these lines, Guru criticizes dominant discourses that would deny the Afrological origins of jazz, as in the case of Paul Whiteman, a white bandleader of the 1920s and 1930s who fronted a commercially-successful all-white orchestra that played jazz-influenced popular music. Although he is said to have cared little for the title, Whiteman was widely promoted as the "King of Jazz" by the industries that surrounded his music at the time (Rayno 32-33, 94). The lyrics of "Jazz Thing" offer a forceful challenge to this pattern of colonizing appropriation, of which Paul Whiteman's career is but one example. ${ }^{12}$ 
Critical Studies in Improvisation / Études critiques en improvisation, Vol 10, No 1 (2014)

"Jazz Thing" concludes with the following prognostication:

Now there's young cats blowin'

And more and more people, yes they will be knowin'

Jazz ain't the past; this music's gonna last

And as the facts unfold, remember who foretold

The ' 90 's, will be the decade of a jazz thing.

Gang Starr insists that the jazz tradition isn't just about the musical and cultural past, but also about animating the present and the future. The clear implication is that hip-hop culture is related to jazz at a fundamental level, and that through the efforts of hip-hop artists such as Gang Starr, more and more people will know that "jazz ain't the past; this music's gonna last." But it won't necessarily last in static, reified form. Even as Gang Starr's work memorializes jazz, it radically transforms it, suggesting that what will last—if jazz is to remain a vibrant, developing art form-is jazz as a creative process, not a product to be preserved, packaged, and sold. ${ }^{13}$

In hindsight, the 1990s as a whole may not have been the decade of a "jazz thing," but the early part of the decade did witness widespread interest in jazz, particularly in hip-hop circles. Gang Starr's Guru remained at the forefront of this movement with his Jazzmatazz series. Released in 1993, Jazzmatazz, Volume 1 combines Guru's skills with those of a range of musicians who share a common locus in jazz. ${ }^{14}$ Featured guests include saxophonists Branford Marsalis and Courtney Pine (who both had roughly concurrent musical projects that combined elements of jazz and hip-hop), as well as musicians associated with the then burgeoning acid jazz movement, namely guitarist Ronny Jordan and vocalists Carleen Anderson (of Young Disciples) and N'Dea Davenport (of Brand New Heavies). ${ }^{15}$ Jazzmatazz also includes Senegalese-born, Francophone rapper MC Solaar. Trumpeter Donald Byrd, pianist Lonnie Liston Smith, and vibraphonist Roy Ayers round out the list of guest musicians, adding considerable historical depth to the recording - all three musicians had lengthy careers performing and recording in various post-bop jazz styles including numerous funk-jazz projects from the 1970s that had long served as hip-hop sampling sources.

In the opening track on Jazzmatazz, Guru discusses the concept of the project against a repeated 5-note trumpet motif played by Donald Byrd: "Welcome to Jazzmatazz, an experimental fusion of hip-hop and live jazz [. . .] hip hop, rap music_-it's real. It's musical, cultural expression based on reality. And at the same time, jazz is real and based on reality." Guru makes a similar statement in an interview with Kronick magazine in which he objects to his music being described as jazz-rap: "when they tried to label us Jazz Rappers I was like, 'We ain't Jazz Rap! This is Reality Rap; this is Real Shit and it's getting Realer as it goes along"' (Gang Starr, "Lock and Load" par. 21, caps in original). Guru's distaste for the jazz-rap label and his insistence that his music is rooted in reality might be seen as a challenge to industry-enforced stylistic labels. Such labels (even hybridized ones such as "jazz-rap") frequently work to limit creative mobility within Afrological forms. Stylistic labels also contribute to a revolving-door mentality in which only the latest trends are celebrated: use value is constantly displaced by exchange value by the profit-driven music industry. Guru explains, "We never wanted to be categorized as jazz-rap [ . . ] because we figured that if that happened, when jazz-rap was finished, we'd be finished. And truth be told, there's no one else from that era who's still around. Those are all my peoples, but I didn't want that happening to us" (qtd. in Rotondi par. 9).

Guru's insistence that his "experimental fusion" of jazz and hip-hop is based on reality, on the shared "real-ness" of the two genres, can also be seen as a carefully constructed discursive move that justifies the project to mainstream hip-hop audiences. As he elaborates in the album's liner notes, "My main concern was to maintain my street credibility and to represent the hardcore rap crowd because they've got me to where I am now" (qtd. in Adler). In hiphop circles, the term "hardcore" usually denotes rap music with lyrics that discuss issues associated with inner-city life, including poverty, racism, drug abuse, and street violence. Originally, hardcore hip-hop included political and socially conscious groups such as Gang Starr and Public Enemy, but by the early 1990s, hardcore came to be increasingly identified with West Coast gangsta rap in which a hypermasculine thug image became one of the main pre-requisites for "keeping it real." ${ }^{16}$ By asserting that both hip-hop and jazz are "based on reality," Guru insists that his music is still hardcore, still rooted in the realities of urban African American experience. In the Jazzmatazz series, he uses jazz as an alternate strategy to articulate a sense of musical and cultural authenticity, without pandering to the themes of violence, homophobia, materialism, and misogyny prevalent in much gangsta rap.

By bringing together musicians from a variety of musical, national, gender, generational, and linguistic backgrounds, Guru's improvisatory fusion of hip-hop and live jazz articulates a view of the African diaspora that juxtaposes multiple histories and narratives without sacrificing the individual identities of the participants. Guru is careful to acknowledge 
all of the musicians involved in the project on the tracks, "Introduction" and "Respectful Dedications," as well as in the liner notes, wherein he thanks each guest individually. Musically too, the vocalists and instrumental soloists on Jazzmatazz Vol. 1 engage with Guru's beats and rhymes in an improvisatory way that respects, even celebrates, musical and cultural differences. Perhaps the clearest example of this is the inclusion of MC Solaar, who raps in his native French on the track "Le Bien, Le Mal" alongside Guru's rapping in English.

A brief description in Jazzmatazz Vol. 1's liner notes of the in-studio interaction between Guru and the jazz instrumentalists provides further evidence of the dialogic and improvisatory nature of the recording process: "[Guru would] record the basic rhythm track, choose a title, have the jazzman come in and solo, and write his lyrics in the studio as the instrumentalist played" (Adler). This process affirms the centrality of improvisation in the creative process behind the recording: just as the jazz musicians improvised over Guru's backing tracks, Guru would improvise lyrics in the studio as the musicians played-a dynamic exchange of musical and generational call and response between jazz and hip hop cultures.

\section{Reclaiming Stolen Moments: Jazz-rap, AIDS, and the New Cultural Politics of Difference}

The 1994 compilation album Stolen Moments: Red Hot + Cool might be seen as the culmination of the jazz-rap trend of the early 1990s. The recording was organized by the Red Hot Organization, a not-for-profit group founded in 1989 with the goal of harnessing "the power of popular culture to raise awareness (and funds) in the fight against AIDS" (ITVS par. 1). This has entailed the release of over a dozen commercial recordings and several televised music specials that have collectively netted more than 10 million dollars for AIDS research and education as of 2014. Stolen Moments: Red Hot + Cool, the fifth installment in the Red Hot AIDS Benefit Series, was intended to heighten awareness about HIVIAIDS in inner-city African American communities specifically.

In the United States, African Americans have been disproportionately affected by the HIVIAIDS epidemic. A study from the year 2000 found that "Of all races, African Americans have the highest HIV prevalence, HIVIAIDS incidence, HIV mortality, and the greatest number of years of potential life lost" (Smith et al 1245). African Americans living with HIVIAIDS have also faced greater barriers to accessing health care than their white counterparts historically (M. Shapiro et al; Fleishman et al). There is also evidence to suggest that African Americans face significant barriers to HIVIAIDS education, prevention, and awareness (Dusenbury et al; Aruffo et al). In the face of such obstacles to AIDS awareness in African American communities, the Red Hot Organization created the Stolen Moments: Red, Hot + $\mathrm{Cool}$ project, a commercially released compilation album and a film of the same name, each documenting a historic convergence of jazz and hip-hop musicians.

The title of the Stolen Moments project is derived from a 1961 Oliver Nelson recording of the same name on his classic album Blues and the Abstract Truth. ${ }^{17}$ "Stolen Moments" (which is covered on the Red Hot compilation by the Japanese acid jazz group United Future Organization) thus serves as a reminder of both the rich legacy of classic jazz and the fact that AIDS has "stolen moments" from the lives of many African American families and other families around the globe.

In addition to the title track, the recording features collaborations between Donald Byrd, Guru, and Ronny Jordan; MC Solaar with jazz bassist Ron Carter; Meshell Ndegeocello with Herbie Hancock; The Roots with Roy Ayers; US3 with Joshua Redman; and others. Several songs feature lyrics that deal with issues related to HIVIAIDS, including safe sex ("The Rubbers Song" by Pharcyde and "Positive" by Michael Franti and Spearhead), drug use ("Flying High in the Brooklyn Sky" by Digable Planets with Lester Bowie and Wah Wah Watson), and outrage ("This is Madness" performed by Umar Bin Hassan and Abiodun Oyewole of the Last Poets with Pharoah Sanders).

The album's liner notes include photographs of many of the performers on the recording, as well as a statement that elaborates on the intentions behind the project:

This album concentrates on the jazz thing not only because it is happening now, but also because jazz brings more to hip-hop than just fresh beats and clever samples. The spiritual dimension of jazz, particularly the cool bebop of Charlie Parker and Thelonious Monk through Miles Davis and John Coltrane, shows how to make popular music a form of serious creative expression rather than mere mass entertainment. The spirit of jazz can help teach us the self-awareness and social consciousness that we need to survive in a world where random violence, drug abuse, economic apartheid and AIDS have become a part of everyday life. (Carlin 1994)

Positing jazz as both popular music and "a form of serious creative expression," this statement implies that hip-hop artists can develop greater self-awareness and social consciousness by drawing on elements of jazz music and 
culture. Presumably, the "spirit of jazz" in this context refers not only to an emphasis on improvisation and musical dialogue, but also to the importance of knowing the musical and cultural past that informs one's own performance practice.

The Stolen Moments film includes footage of live performances by many of the musicians on the album interspersed with footage of inner-city street scenes, interviews with African Americans living with AIDS, and interviews in which the Stolen Moments performers discuss their views on AIDS and AIDS-related issues including safe sex, homophobia, and conspiracy theories concerning the origins of the disease. The interview and street-scene portions of the film are shot in black and white, referencing earlier filmic representations of jazz and accentuating the bleak social conditions that surround African Americans living with AIDS in the inner city. Taken together, these fragments provide an honest portrait of AIDS, and the perceptions of AIDS, in African American communities in the early to mid 1990s.

Of the featured musical performers in the film, only Meshell Ndegeocello, who is openly bisexual, brings a nonheterosexual subject position to the project. ${ }^{18}$ She also brings considerable musical mobility in that she routinely draws on a host of Afrological forms including not only jazz and hip-hop, but also funk, soul, reggae, R\&B, and rock. For Mark Anthony Neal, Ndegeocello epitomizes what he, drawing on the work of Masani Alexis De Veaux, terms "newblackness": "a radical fluidity within 'blackness' that crosses genders, sexualities, generations, religions, ethnicities, and whatever attributes individual 'black people' claim as being part of the blackness they possess" (Songs 5). In Stolen Moments, Ndegeocello's "radical fluidity" challenges received notions of African American identity, the perceived autonomy of Afrological musics such as jazz and hip-hop. It also challenges the continued prevalence of homophobia in many African American communities and in society more generally.

One of the most compelling sections of the Stolen Moments film consists of an audio-visual montage that juxtaposes sound bytes, images, and interview footage drawn from the rest of the film. Sonically, this sequence is held together by fragments of Max Roach's recording of "Garvey's Ghost" from his 1961 Impulse! album Percussion Bitter Sweet. Organized around a West-African-derived 12/8 cowbell pattern, the piece serves as musical ground upon which various figures, in the form of film and audio samples, are superimposed, punctuating the flow of music. As we hear Roach soloing atop the recursive bell pattern, images from the film, many of them just single frames, are cut to the rhythm of the drum solo. Stolen Moments executive producer John Carlin remembers the impetus behind the montage: "the show was feeling too conventional and I wanted its form to be as dynamic as the subject matter. I used Max to set a rhythmic pulse that I tried to recreate visually through edits and discontinuities in the edits. We literally randomized images in the machine, created 'mistakes' and then smoothed them out again." 19 As the sonic and visual intensity builds, a saxophone solo by Pharoah Sanders is layered on top of the Roach recording, creating a dense cacophony of sound. At different points, "Garvey's Ghost" is interpolated with samples of The Roots performing "Proceed II," their contribution to the Stolen Moments album. In combination, these musical elements articulate a deep sense of cultural memory, given the way this sequence connects different facets of jazz (Roach's drum solo and Sander's wailing tenor saxophone) and hip-hop (The Roots' "Proceed II") to West African musical and cultural heritage (the underlying $12 / 8$ bell pattern).

The use of "Garvey's Ghost" as the musical and metaphoric ground for this section is also significant. The founder of the Universal Negro Improvement Association and African Communities League (UNIA-ACL), Marcus Garvey was a Jamaican-born, Black, Nationalist leader who advanced Pan-African philosophy and solidarity during the 1920s and 1930s. Roach's composition honours Garvey's legacy by articulating a sense of musical Pan-Africanism. The inclusion of "Garvey's Ghost" in Stolen Moments suggests that Garvey's Pan-Africanist ideology continues to stir in African American and African-diasporic communities, providing a model of solidarity and insurgency in the face of the AIDS epidemic.

In many ways, the Stolen Moments project embodied what Cornel West described in the early 1990s as the "new cultural politics of difference," which he defines as "distinct articulations of talented (and usually privileged) contributors to culture who desire to align themselves with demoralized, demobilized, depoliticized and disorganized people in order to empower and enable social action, and, if possible, to enlist collective insurgency for the expansion of freedom, democracy, and individuality" (Keeping 3-4). Interestingly, West actually appears in the Stolen Moments documentary, and some of his statements in the film are included in the liner notes to the album. ${ }^{20}$ As one of the most respected and influential contemporary African American public intellectuals, West brings considerable academic heft to the program and its message concerning the gravity of the AIDS epidemic in African American communities, while tempering the conspiracy theories concerning the disease that are presented by many of the musicians in the film:

The effects and consequences could lead one to think that there's a conspiracy because they are that bad. At the same time, the conspiracy is a cry of urgency for the situation. Whether there is actually a conspiracy, I don't think so. But ultimately that is not the issue 
because to say there's not a conspiracy can reinforce complacency. But the sense of urgency is real and the effects and consequences are overwhelming, and therefore we all ought to be standing at the edge of the abyss and crying out, 'We've got to do something!'

West also uses his appearance to offer a thoughtful critique of hip-hop culture. His comments are worth quoting at length:

\begin{abstract}
In hip-hop, you have a variety of different voices. You have some progressive voices. You have some voices that are relatively indifferent to the issue, highlighting other issues, and you have some voices that are downright retrograde and reactionary, that reinforce the same homophobic stereotypes, the same misogynist stereotypes. But it's important to highlight the diversity, and I think it's a challenge to young artists in hip-hop culture to represent the best of the black freedom struggle, which is to stay in contact with the humanity of every member of the black community, which allows you to stay in contact with the humanity of each and every member of the human family. And that means, of course, calling into question homophobia, calling into question misogyny and patriarchal sensibilities, calling into question class arrogance, and calling into question the sense of feeling that somehow by reproducing the same kind of stereotypes that one is powerful, that one can pose and posture in the same form of power that is being used against one.
\end{abstract}

In retrospect, it would seem that many of the performers involved with the Stolen Moments project heeded West's call, "align[ing] themselves with demoralized, demobilized, depoliticized and disorganized people in order to empower and enable social action, and, if possible, to enlist collective insurgency for the expansion of freedom, democracy, and individuality" to quote again from West's conception of a new cultural politics of difference (Keeping 4). In the late 1980 s and early 1990s - a time period many commentators (including this one) think of as the golden age of hiphop-part of this collective insurgency involved the memorialization and strategic deployment of jazz, an improvisatory Afrological form that, for many people, embodies the values of freedom, agency, and individuality. By engaging jazz as a form of cultural memory, jazz-rap mobilized the musical past in the service of a sociallyprogressive cultural politics of difference.

\title{
Notes
}

${ }^{1}$ A variety of alternative epithets have been used to describe jazz-rap. For example, in Rap Music and the Poetics of Identity, Adam Krims used the term "Jazz/Bohemian" to refer to this subgenre (65). The term "jazz hop" is also used in some contexts to refer to jazz/hip hop crossovers. This term is more inclusive than "jazz-rap" in the sense that it encompasses instrumental forms of jazz-infused hip-hop, in addition to jazz-infused rap specifically. I use the term "jazz-rap" in the present context because this term has been in wider circulation historically and because I am writing primarily about projects that involve MCs. I also hyphenate the term "jazz-rap" in order to emphasize the relational aspects between the two genres involved: for me, the hyphen symbolizes the spirit of musical and cultural dialogue inherent in many jazz/hip-hop hybrids.

${ }^{2}$ Nelson George provides a detailed account of his interview with Mtume and of Stetsasonic's response in Hip Hop America (89-90).

${ }^{3}$ In his essay "The Construction of Jazz Rap as High Art in Hip-Hop Music," Justin Williams refers to such signifiers and their sonic equivalents (for example walking bass lines, "swung" eighth notes, etc.) as "jazz codes" that jazz-rap performers drew on to set their music apart from gangsta rap and other subgenres of hip-hop, articulating a "high art ideology" in the process.

${ }^{4}$ This footage was released on video in 1987 as The Spirit Moves: A History of Black Social Dance on Film.

${ }^{5}$ For additional instances of the vitriolic backlash to rap in the early 1990s, see J.D. Considine's 1992 article "Fear of a Rap Planet." Considine quotes several musicians including Al Di Meola, Lita Ford, and Ozzy Osbourne who each criticize rap as boring and un-melodic: "It's not music," states Di Meola. "It's not like I'm hearing an instrumentalist play, with some harmony and a good vocalist. Where are the people who've learned to play their instrument?" In 
1991, the New Republic ran a cover story on rap music titled "The Rap on Rap: The 'Black Music' that Isn't Either" (Samuels). The article's subtitle denies not only rap's status as music, but also its status as an Afrological mode of music making because of rap's largely white listenership. For a roughly contemporaneous defense of the aesthetics of rap music, see Richard Shusterman's essay "The Fine Art of Rap" (1991).

${ }^{6}$ Eric B. \& Rakim's version of "I Know You Got Soul” samples two recordings by The J.B.'s, James Brown's backing band in the early 1970s: "The Grunt," an instrumental single released in 1970; and the original version of "I Know You Got Soul," released in 1971 by Bobby Byrd and the J.B.'s.

${ }^{7}$ It should be noted that DJ Premiere was not the only producer at the time incorporating jazz samples into hip-hop. In the early 1990s, Pete Rock also developed a horn-heavy, jazz-oriented approach to beat production that can be heard on albums such as Mecca and the Soul Brother by the duo Pete Rock and CL Smooth.

${ }^{8}$ In her introduction to Acts of Memory, Mieke Bal writes, "the term cultural memory signifies that memory can be understood as a cultural phenomenon as well as an individual or social one. [. . C]ultural memorialization [is] an activity occurring in the present, in which the past is continuously modified and redescribed even as it continues to shape the future" (vi). For a discussion of cultural memory in relation to Afrological modes of music making, see Floyd (1995) and Ramsey (2003).

${ }^{9}$ Lee had already played a role in one jazz/hip-hop encounter. His landmark 1989 film Do the Right Thing prominently features Public Enemy's classic anthem of resistance: "Fight the Power." Through Lee, the members of Public Enemy met jazz saxophonist Branford Marsalis, who was also involved in the film's soundtrack. As a result of this encounter, Marsalis contributed a saxophone solo for the single release of "Fight the Power." See Walser (19899) for a discussion of the different conceptions of musicianship involved in the encounter.

${ }^{10}$ For a discussion of musical abstraction in modern jazz, see Stewart (2011). Adam Krims notes that performers working within jazz-rap (what he refers to as "Jazz/Bohemian") are known for "the complexity and abstraction of their lyrics," which I understand to mean a move away from literal, lyrical representations towards non-material concepts such as beauty, truth, and justice.

${ }^{11}$ It is perhaps worth noting in this context that Spike Lee's production company is named "40 Acres \& A Mule Filmworks," in reference to the broken promise of 40 acres of land and a mule for freed African American slaves after the abolishment of legal slavery in the United States.

12 In the 1930s, the record industry crowned Benny Goodman "King of Swing"; in the 1950s, Elvis Presley was declared the "King of Rock and Roll."

${ }^{13}$ The idea of jazz as a process recalls the work of Christopher Small, who famously coined the term "musicking" to emphasize music as a verb rather than a noun or product. Similarly, in his influential book Blues People, Leroi Jones/Amiri Baraka made a distinction between the concept of "swing" as a verb and as a noun. Baraka characterizes the co-optation and commodification of swing music by largely white interests as shifting the conception of the music from verb to noun. Building on Baraka's work, Nathaniel Mackey has contrasted the "domain of action and the ability to act suggested by verb" within Afrological modes of expressive culture with the "hypostasis, paralysis, and arrest suggested by noun." He concludes by stressing the need to "confront the neotraditionalism that has taken hold of late with a counter tradition of marronage, divergence, flight, and fugitive tilt" (68). I would suggest that within the context of the early 1990s, jazz-rap represented one such counter tradition.

${ }^{14}$ Guru went on to release three additional volumes in the Jazzmatazz series before his untimely death in 2010 : Volume 2 in 1995, Volume 3 in 2000, and Volume 4 in 2007.

15 "Acid jazz" is a loosely defined musical genre that developed first in England in the late 1980s and early 1990s. The music is typically characterized by a combination of jazz melodic and harmonic concepts with soul, funk, disco, and electronic dance grooves. Acid jazz and jazz-rap ought to be understood as concomitant phenomena given the fact that they emerged at roughly the same time, and the fact that there was widespread collaboration between the musicians involved in the two genres. 
${ }^{16}$ For an overview of gangsta rap and its relationship to other facets of hip-hop, see Quinn (2004) and Chang (2005). For a discussion of hip-hop notions of authenticity and "keeping it real," see Ogbar (2007).

17 The makers of Stolen Moments: Red Hot + Cool used the project as leverage to convince GRP records (then owned by MCA) to resurrect the Impulse! record label and re-release many titles in the label's back catalogue of classic jazz recordings made during the 1960s and 1970s. As part of this enterprise, Stolen Moments includes a bonus CD containing abridged versions of John Coltrane's A Love Supreme by Branford Marsalis and Alice Coltrane, as well as a "trip hop remix" of Pharoah Sanders's "The Creator has a Master Plan." In 1995, GRP released a companion album to Stolen Moments titled Red Hot on Impulse, which includes a cross-section of the label's spiritually and politically-oriented recordings by artists including John Coltrane, Alice Coltrane, Archie Shepp, Lonnie Liston Smith, Max Roach, and Charles Mingus. Oliver Nelson's original version of "Stolen Moments" appears in that context as well.

${ }^{18}$ Ndegeocello would go on to collaborate with Queen Pen on the 1997 recording "Girlfriend." Based loosely on Ndegeocello's "If That's Your Boyfriend (He Wasn't Last Night)," "Girlfriend" was the first commercial hip-hop recording to address same-sex desire.

19 John Carlin, e-mail message to author, November 18, 2007.

${ }^{20}$ West has engaged with-and in-aspects of hip-hop culture in other ways as well. For example, he participated in discussions as part of hip-hop mogul Russell Simmons's Hip-Hop Summit in 2001. He is also interviewed in the 1993 documentary The Darker Side of Black, which takes a critical look at misogyny and homophobia in rap and reggae. More recently, West released Never Forget: A Journey of Revelations on which he collaborates with hip-hop artists including Talib Kweli, KRS-One, and Andre 3000.

\section{Works Cited}

Adler, Bill. Liner Notes. Jazzmatazz, Volume 1. Chrysalis, 1993. Print.

Aruffo, J. F., et al. "AIDS knowledge in low-income and minority populations." Public Health Reports 106.2 (1991): 115-119. Print.

Bal, Mieke. "Introduction." Acts of Memory: Cultural Recall in the Present. Ed. Mieke Bal, Jonathon Crewe, and Leo Spitzer. Hanover: UP of New England, 1999. vii-xvii. Print.

Big Daddy Kane. "Word to the Mother(Land)." Long Live the Kane. Cold Chillin'/Warner Bros., 1988. CD.

Brown, James. "Bring it Up (Hipster's Avenue)." Star Time (Boxed Set). Polydor, 1991. CD.

Byrd, Bobby. "I Know You Got Soul." 1971. Bobby Byrd Got Soul: The Best of Bobby Byrd. Polydor, 1995. CD.

Carlin, John. Email to author. 18 Nov. 2007.

---. Liner Notes. Stolen Moments: Red Hot + Cool. GRP, 1994. Print.

---. Personal Interview. 13 Nov. 2007.

Chang, Jeff. Can't Stop Won't Stop: A History of the Hip Hop Generation. New York: St. Martin's, 2005. Print.

Coltrane, John. Afro-Blue Impressions. Pablo, 1963. CD.

---. A Love Supreme. Impulse!, 1964. CD.

---. Giant Steps. Atlantic, 1960. CD. 
---. "The Promise." Live at Birdland. Impulse!, 1963. CD.

---. "Wise One" Crescent. Impulse!, 1964. CD.

Coleman, Ornette. "Invisible." The Music of Ornette Coleman: Something Else!!!. 1958. Fantasy, 2006. CD.

Considine, J.D. "Fear of a Rap Planet." Musician (February 1992): 34-43, 92. Print.

The Darker Side of Black. Dir. Issaac Julien. Arts Council of Great Britain, 1993. DVD.

Dehn, Mura, dir.. The Spirit Moves: A History of Black Social Dance on Film. Filmmakers Library, 1987. DVD.

Dusenbury L., et al. "Attitudes toward AIDS and AIDS education among multi-ethnic parents of school-aged children in New York City." AIDS Education Preview 6.3 (1994): 237-248. Print.

Ellison, Ralph. Invisible Man. New York: Random House, 1952. Print.

Eric B. \& Rakim. "I Know You Got Soul." Paid in Full. Zakia/4 ${ }^{\text {th }} \&$ Broadway, 1987. CD.

Fleishman, J.A. et al. Hospital and outpatient health services utilization among HIV-infected adults in care 20002002." Medical Care 43.9 (1999): 40-52. Print.

Floyd, Samuel A. The Power of Black Music. New York: Oxford UP, 1995. Print.

Gang Starr. “Jazz Music.” No More Mr. Nice Guy. Wild Pitch/EMI, 1989. CD.

---. “Jazz Thing.” Music From Mo Better Blues. Columbia, 1990. CD.

---. “Jazz Thing.” YouTube. 13 Apr. 2008. Web. 9 Nov. 2014.

---. “Jazz Thing (Video Mix)." Full Clip: A Decade of Gang Starr.” Virgin, 1999. CD.

---. "Lock and Load: Interview with Meshack Blaq." Kronick. Web. 10 Sept. 2014. <http://www.kronick.com/2.0/issue21/gangstarr.shtml>.

---. "Who Got Gunz." The Ownerz. Virgin/EMI, 2003. CD.

---. "Words I Manifest." No More Mr. Nice Guy. Wild Pitch/EMI, 1989. CD.

George, Nelson. Hip Hop America. New York: Penguin, 1998. Print.

Guru. Jazzmatazz, Volume 1. Chrysalis, 1993. CD.

---. Jazzmatazz, Volume 2: The New Reality. Chrysalis, 1995. CD.

---. Jazzmatazz, Volume 3: Streetsoul. Virgin Records, 2000. CD.

---. Jazzmatazz, Volume 4. 7 Grand Records, 2007. CD.

ITVS. "About Stolen Moments: Red Hot + Cool." Web. 18 Oct 2014. <http://archive.itvs.org/external/RHC/RedHot_project.html>.

The J.B.'s. "The Grunt." Food For Thought. People, 1972. CD.

Jones, Leroi. Blues People: Negro Music in White America. New York: Morrow Quill Paperbacks, 1963. Print. 
Krims, Adam. Rap Music and the Poetics of Identity. Cambridge: Cambridge UP, 2000. Print.

Lewis, Ramsey. "Les Fleur.” 1968. Maiden Voyage. Universal, 2006. CD.

Mackey, Nathaniel. "Other: From Noun to Verb." Representations 39 (Summer 1992): 51-70. Print.

Mo’ Better Blues. Dir. Spike Lee. Perf. Denzel Washington, Spike Lee, Wesley Snipes. Universal, 1990. DVD.

Ndegeocello, Meshell. "If That's Your Boyfriend (He Wasn't Last Night)." Plantation Lullabies. Maverick, 1993. CD.

Nelson, Oliver. Blues and the Abstract Truth. Impulse!, 1961. CD.

Nicholson, Stuart. Is Jazz Dead? (Or Has it Moved to a New Address). New York: Routledge, 2005. Print.

Ogbar, Jeffrey. Hip-Hop Revolution: The Culture and Politics of Rap. Kansas: UP of Kansas, 2007. Print.

Pete Rock and CL Smooth. Mecca and the Soul Brother. Elektra Records, 1992. CD.

Public Enemy. "Fight the Power," extended version. Motown, 1989. CD.

Queen Pen. "Girlfriend.” My Melody. Universal Music Group, 1997. CD.

Quinn, Eithne. Nuthin' but a "G" Thang: The Culture and Commerce of Gangsta Rap. New York: Columbia UP, 2004. Print.

Parker, Charlie. "A Night in Tunisia." 1946. Charlie Parker: Complete Savoy \& Dial Sessions. Definitive Records, 2001. CD.

Ramsey, Guthrie P. Race Music: Black Cultures from Bebop to Hip-Hop. Berkeley: U of California P, 2003. Print.

Rayno, Don. Paul Whiteman: Pioneer in American Music Volume 1: 1890-1930. Lanham: Scarecrow, 2003. Print.

Roach, Max. Percussion Bitter Sweet. Impulse!, 1961. CD.

Samuels, David. “The Rap on Rap: The ‘Black Music' That Isn't Either.” New Republic (Nov. 1991): 24-29. Print.

Shapiro, Martin F., et al. "Variations in the Care of HIV-Infected Adults in the United States." Journal of the American Medical Association. 281.24 (1999): 2305-2315. Print.

Small, Christopher. Musicking: The Meanings of Performing and Listening. Middletown: Wesleyan UP, 1998. Print.

Shusterman, Richard. "The Fine Art of Rap." New Literary History 22.3 (Summer 1991): 613-632. Print.

---. Pragmatist Aesthetics: Living Beauty, Rethinking Art. Cambridge: Blackwell Publishers Inc. 1992. Print.

Smith, Dawn K., et al. "HIVIAIDS among African Americans: progress or progression?" AIDS. 14.9 (2000): 12371248. Print.

Smith, Lonnie Liston. “Expansions.” Expansions. LP. Flying Dutchman, 1974. CD.

Stetsasonic. “Talkin' All That Jazz.” Dir. Fab Five Freddy. YouTube. 25 Aug. 2008. Web. 9 Nov. 2014.

Stetsasonic. Liner Notes. In Full Gear. 1988. Tommy Boy, 2001. Print.

---. “Talkin' All That Jazz.” In Full Gear. Tommy Boy, 1988. CD. 
Stewart, Jesse. “No Boundary Line to Art: ‘Bebop' as Afro-Modernist Discourse.” American Music 29.3 (Fall 2011 ): 332-352. Print.

Stolen Moments: Red Hot + Cool. Dir. Earle Sebastian. Perf. Donald Byrd, Guru, Ronny Jordan, MC Solaar, Ron Carter, The Pharcyde, Meshell Ndegeocello, Joshua Redman, Umar Bin Hassan and Abiodum Oyewole, Pharoah Sanders, Digable Planets, Lester Bowie, Joe Sample, Wah Wah Watson, Carleen Anderson, Groove Collective, The Roots, Cornel West. VHS. Polygram Video, 1994. DVD.

Various Artists. Red Hot on Impulse! GRP, 1995. CD.

---. Stolen Moments: Red Hot + Cool. GRP, 1994. CD.

Walser, Robert. "Rhythm, Rhyme, and Rhetoric in the Music of Public Enemy." Ethnomusicology 39.2 (Spring/Summer 1995): 193-217. Print.

West, Cornel. Keeping Faith: Philosophy and Race in America. New York: Routledge, 1993. Print.

West, Cornel \& BMWMB. Never Forget: A Journey of Revelations. Hidden Beach Forum, 2007. CD.

Williams, Justin. "The Construction of Jazz Rap as High Art in Hip-Hop Music." Journal of Musicology. 27.4 (October 2010): 435-459. Print. 